\title{
Analysis of the Relationship Between Body Perception Levels and Social Appearance Anxieties in the Students of School of Physical Education and Sports
}

\author{
Turan Çetinkaya \\ Correspondence: Turan Çetinkaya, Ahi Evran University, Turkey.
}

\author{
Received:March 25, 2018 \\ Accepted: April 21, 2018 \\ Online Published: April 25, 2018 \\ doi:10.11114/jets.v6i5.3115 \\ URL: https://doi.org/10.11114/jets.v6i5.3115
}

\begin{abstract}
The aim of this research is to analyse the relationship between body perceptions and social appearance anxiety of the students that are in physical education and sports departments. 240 students that are studying in the departments of Physical Education and Sports Teaching, Sports Management and Coaching Training at Ahi Evran University, School of Physical Education and Sports, participated in the research. Personal information form, body perception scale and social appearance anxiety scale were used as data collection tools in the research. Distribution, frequency, $t$ test and colleration analysis were performed in comparison of the relevant data. As a result of statistical analysis, there was no significant difference in body perception scores of the participants in terms of gender, smoking and alcohol use, but there was a significant difference in terms of licensed athletic variances. In the colleration analysis, significant negative relation between the participants' body perceptions and social anxiety scores were detected.
\end{abstract}

Keywords: body perception, social appearance anxieties, schools of physical education and sports

\section{Introduction}

Studies on body perception were seen to focus primarily on three areas. These areas are the body image (Herzog, 1992) body satisfaction (Dolan, 1987) and less frequently self-perception (Franzoi, 1989). The body image can be expressed as an identity or an explicit dimension of the physical self, or a body image that was perceived in the mirror or pictured in the mind (Traub \& Orbach, 1964). Body sensation refers to the views and attitudes of the individual with regard to their physical appearance in terms of size and aesthetics. Internal body sensation is the design of the physical self of the individual and includes pain, touch, posture change, thirst, or sexual experiences. The external body perception is the aspect that the individual is perceived by other individuals in the society (Dökmen, 1996; Dökmen, 2004). Body perception has a significant impact in the development of the personality, boosting self-confidence, being a social person, and being mentally, physically and psychologically healthy of the individual (Öksüz, 2012). It is usual for an individual who sees himself physically sufficient or who is perceived by others as such to love his body and to think that he can be physically self-sufficient. It is also usual that the basic structures of the self such as the level of self-esteem become high as a result that the perceived physical sufficiency is high. It is known that being physically well affects psychological development (Yentur, 2004). Attributing certain meanings to the body and the body parts of the individual is closely related to the concepts of self-confidence, self-esteem (self-respect), self-perception, identity and personality (Aslan, 2004). The formation of the body perception of the individual starts with the development of physical and abstract thinking ability as he ends his childhood and reaches his adolescent (Harris, 1987). Walster and his colleagues (1966) report in their study that people are highly influenced by physical attractiveness and that physical attractiveness is more prevalent in human variances such as intelligence, independence, sensitivity, and sincerity. Öksüz (2012) states that those who have high body perception, who love their body, and who are pleased with their body live at peace with themselves and in harmony with the environment. According to the author, the individual who developed the power to act autonomously has developed the ability to self-control, to take responsibility for his behavior, to interpret professional and values, and to establish independent but warm relations with the family In other words, it is expected that individuals with high autonomous behavior ability will develop more balanced and healthy relationships.

Hart and his colleagues (2008) state that social appearance anxiety is a broader concept including body perception and body image characteristics such as skin color and face shape (nose, distance of eyes, smile) beyond the general physical appearance such as height, weight and muscle structure. Doğan (2010) states that social appearance anxiety refers to the 
anxiety about the physical appearance of the individual and also the anxiety about the judgement made by others about the individual. The author defines the social anxiety as the anxiety that is experienced based on negative body perception. Clark \& Wells (1995) states that social appearance anxiety is as a consequence of a negative body image related to body and appearance of the individual. The authors report that most socially anxious people have negative beliefs about their own value and importance as it is also experienced in depression. Individual who is pleased with his appearance is considered as an individual whose self-confidence is high, social communication skills are proper, physical and mental health are balanced. Individuals who is not pleased with his appearance, on the other hand, is considered as an individual whose self-confidence and quality of life are low, and who are less able to cope with physical, psychological and social problems (Crerand, Infield \& Sarwer 2007). People who evaluate themselves positively in physical terms are more secure in interpersonal relationships and more successful in their work, while those who are not pleased with themselves and who think that they have many defective parts in themselves have constantly restless, insecure and worthless feelings at various periods of their lives (Demirer, 2005). Gümüş (2000) states that an important determinant of the perception of the individual's appearance is self-esteem. CooperSmith (1967) reports that low self esteem causes people to feel worthless, weak and lonely. These people tend to avoid a close relationship in society.

Social anxiety and body perception is defined as a dynamic concept that begins to develop in infancy, gains importance especially during adolescence, and involves the subjective perception of the individual who develops and changes throughout life (Anbar, 2013). The aim of this research is to reveal the relationship between the body perception levels and social appearance anxiety of the students who are studying at the school of physical education and sports within this whole conceptual framework.

\section{Method}

\subsection{Population and Sampling}

The population of this study consisted of male and female students who are studying in the department of Physical Education and Sports Teaching, Coaching Education and Sports Management at Ahi Evran University, School of Physical Education and Sport in 2017-2018 education period. The research population consisted of approximately 700 students and the sampling consisted of 240 students.

\subsection{Data Collection Tool}

\section{Body Perception Scale}

The body perception scale developed by Secord and Jourard (1953) aims to measure how pleased the individuals are with various parts of their body and various body functions. The validity and reliability study of the scale in our country was carried out by Hovardaoğlu (1993). The scale contains 40 items, each of which relates to an organ or a part of the body (arm, leg face, etc.) or a function (level of sexual activity). The total score of the scale, which has scores ranging from 1 to 5 for each item and has the response option of "I do not like at all", "I do not like", 'I am uncertain", "I like", "I like a lot" is between 40 to 200 , and the score that is received is high shows that the level of satisfaction is high. The cutoff score of the scale is 135, and those who score below 135 are defined as the lower body perception group (Hovardaoğlu, 1993). In this study, Cronbach's alpha internal consistency coefficient was determined to be 0.964 . (varying value).

\section{Social Appearance Anxiety Scale}

Personal information form and Social Appearance Anxiety Scale that was developed by Hart and his colleagues (2008) and adapted to Turkish by Doğan (2010) was used as data collection tool in the research. The scale is a quinary Likert type scale that has a one-dimensional structure and consists of 16 items. The scale is scored as 1 (not appropriate at all), 2 (not appropriate), 3 (somewhat appropriate), 4 (appropriate) and 5 (fully appropriate). The first item of the scale is coded reversely. Cronbach's alpha internal consistency coefficient scale was found as 0.93 , test retest-test reliability coefficient was found as 0.85 , and reliability coefficient calculated by test half-life method was found as 0.88 . The item-total correlation coefficients of the Turkish form of the scale were found to be between 0,32 and 0,82 (Doğan, 2010). In this study, Cronbach's alpha internal consistency coefficient scale was determined to be 0.937. (varying value).

\subsection{Data Collection}

The questionnaire form used in the research was applied to female and male students who were studying in the department of Physical Education and Sports Teacher Training, Coaching Education and Sports Management at Ahi Evran University School Physical Education and Sports in 2017-2018 education period. The athletes involved in the 
study were given necessary explanations about the purpose of the study prior to their participations in the research, and the detailed information about filling the data collection tool was provided. The data collection tool collected by the researcher was checked and then, those that are valid and acceptable ( 240 pieces) from the data collection form applied to the participants were transferred to electronic medium by being coded for evaluation.

\subsection{Analysis of the Data}

Analysis of data collected in the study was made in SPSS 20.0 statistical package program. In the evaluation of the data; distribution, frequency, $\mathrm{t}$ test, anova and Spearman correlation analysis to determine the relationship between body perception and social appearance anxiety were performed. In the tests that were made for the analysis of the data; the principle of equality of variances from the premises of the parametric tests was taken as a basis, and in the event that variances were not equal, no significant difference was sought between the groups even if the value of "p" was smaller than the significance level. The level of significance in the analyses was determined as $\alpha=0.05$.

\section{Findings}

Table 1. Cronbach's Alpha Internal Consistency Coefficients for Body Perception and Social Appearance Anxiety Scales

\begin{tabular}{lll}
\hline Reliability Statistics & Cronbach's Alpha & N of Items \\
Body Perception Scale & .964 & 40 \\
Social Appearance anxiety Scale & .937 & 16 \\
\hline
\end{tabular}

In table 1, the Cronbach's Alfa analyses of the scales used in this study were carried out, and that of the Body Perception Scale was found as 0,964, while that of the Social Appearance Anxiety was found to be 0,937.

Table 2. Percentage and frequency distributions of descriptive statistics of the participants

\begin{tabular}{cccc}
\hline Variables & Sub-Variables & $\mathrm{f}$ & $\%$ \\
& & & \\
\multirow{3}{*}{ Gender } & Male & 134 & 55,8 \\
& Female & 106 & 44,2 \\
Smoking & Yes & 65 & 27,1 \\
Alcohol use & No & 175 & 72,9 \\
& Yes & 47 & 19,6 \\
Licensed athletic & No & 193 & 80,4 \\
& Yes & 92 & 38,3 \\
Total & No & 148 & 61,7 \\
& & 240 & 100 \\
\hline
\end{tabular}

240 students who were studying at Ahi Evran University, School of Physical Education and Sports participated in the research. 134 students were male and 106 students were students. The number of participants who were smoking was 65 and the number of participants who didn't smoke was 175. The number of participants using alcohol was 47 and the number of participants who did not use alcohol was 193. The number of participants engaged in licensed sports was 92 while the number of those who didn't engaged in licensed sports was 148. (Table 2)

Table 3. T-Test Results for Comparing Body Perception Scores by the Gender of the Participants

\begin{tabular}{clccccc}
\hline Scale & Gender & $\mathrm{n}$ & $\mathrm{x}$ & $\mathrm{ss}$ & $\mathrm{t}$ & $\mathrm{p}$ \\
& Male & 134 & 146.32 & 54.67 &,- 421 & .674 \\
Body Perception & Female & 106 & 149.27 & 52.94 & & \\
\hline
\end{tabular}

*p $<0.05$

There was no significant difference in the comparison of body perception scores by the genders of the participants. When the average scores of the participants were examined, the average scores of female participants were found to be higher than male participants. (male Average $=146.32$, female Average $=149.27$ ).

Table 4. T-Test Results for Comparing Body Perception Scores by the Smoking Status of the Participants

\begin{tabular}{lcccccc}
\hline & Yes & 65 & 143.38 & 55.26 & & \\
Body Perception & & & & & & \\
& No & 175 & 149.20 & 53.36 &,- 743 & .458 \\
\hline
\end{tabular}

$* \mathrm{p}<0.05$ 
There was no significant difference in the comparison of body sensory scores by Smoking Status of the Participants in the study. When the average scores of the participants were examined, the average scores of the non-smokers were higher than the smokers. (smokers Average $=143.38$ non-smokers Average $=149.20$ ).

Table 5. T-Test Results for Comparing Body Perception Scores by the Alcohol Use Status of the Participants

\begin{tabular}{lllllll}
\hline Scale & Alcohol Use & $n$ & $\mathrm{x}$ & ss & $\mathrm{t}$ & $\mathrm{p}$ \\
& Yes & 47 & 140.02 & 53.80 & &
\end{tabular}

Body Perception

$* \mathrm{p}<0.05$

No $\quad \begin{array}{lllll}193 & 149.47 & 53.81 & -1.080 & .281\end{array}$

There was no significant difference in the comparison of body perception scores by the alcohol use status of the participants in the study. (Alcohol users Average = 140,02 non-alcohol users Average $=149,47$ ).

Table 6. T-Test Results for Comparing the Scores of the Body Perception by the Licensed Athletics Status of the Participants

\begin{tabular}{clcccccc}
\hline & Licensed athletic & & & & & \\
Scale & & $\mathrm{n}$ & $\mathrm{x}$ & $\mathrm{ss}$ & $\mathrm{t}$ & $\mathrm{p}$ \\
Body Perception & Yes & 92 & 157.16 & 42.32 & & \\
& & & & & & \\
& No & 148 & 141.69 & 59.24 & 2.181 & .030 \\
\hline
\end{tabular}

$* \mathrm{p}<0.05$

Significant differences were found in the comparison of body perception scores by the licensed athletics status of the participants in the study. The significant difference was favored by licensed athletes. (licensed athletes Average $=157.16$ non-licensed athletes Average $=141.69$ ).

Table 7. Correlation Analysis Results between the Body Satisfaction Levels and Social Appearance Anxiety of the Research Group

\begin{tabular}{ccc}
\hline Variable & Social Appearance Anxiety & Body Perception \\
Body Perception &,$- 473^{* *}$ & 1 \\
\hline
\end{tabular}

$* * \mathrm{p}<0.01$

According to the correlation analysis results, there was a negative, weak and significant correlation between body perception levels and social appearance anxiety of the participants $(r=-0.473, \mathrm{p}<0.01)$.

\section{Discussion And Conclusion}

In this part of the study, findings related to body perception levels of the participants were discussed and the results of these parameters were discussed and interpreted in relation to gender, smoking \& alcohol use and licensed athletics variances. In addition, the relationship between the body perception and social appearance anxiety scores of the research group was revealed and discussed.

According to the findings of the research, there was no significant difference between the body perception scores of the participants in terms of gender variance. When the relevant literature was examined, the study carried out by Köse, Bayköse,Turan ,\& Lapa (2016) support our findings. In terms of gender variance, it is reported that body perception scores of the participants do not vary. Again, Tarhan (1995, Ergür 1996 and Tiegman 2004) stated that there was no significant relationship between body perception and gender in their research. These studies show parallelism with our work. Uskun \& Shabapli (2013) reached different findings from our study in terms of gender variance. The authors found that body perception scores of the female participants were significantly lower than men's. Wardle \& Cooke (2005) and Göksan (2007) found that female participants had lower body perception than men in their studies. The fact that our research group was formed from a pool that generally provided sportive participation could be interpreted as not making a difference in terms of gender variance.

According to our research findings, there was no significant difference in body perception scores between the participants in terms of smoking variance. Pulur and his colleagues (2014) reported that smoking of female and male athletes do not adversely affect their appearances and that they found the appearance of the smokers better than those who do not smoke in the study carried out on folk dancers. Öngören (2015) \& Y1lmaz and their colleagues (2006) 
indicated that body perception scores of the participants did not differ in terms of smoking in their studies. These studies support our findings as their results. Pınar (2002) reported that smoking increased body perception as a coping skill in his research. Again, Stice and Shaw (2002) found that smokers had lower body senses. Again, Stice and Shaw (2002) revealed that smokers had lower body perceptions in their research. These studies differ from our findings. The fact that body perception scores of our research group does not differ in terms of smoking suggests that participants may consider smoking as a coping skill.

There was no significant difference in body perception scores between alcohol use variance of the participants. In parallel to our work, Pulur and his colleagues (2014) reported that alcohol use does not make a difference in terms of significance in the level of perceiving their bodies of female and male folk dancers. Similarly, Öngören (2015) says that alcohol use does not affect body perception in his study. Unlike our findings, Nieri and his colleagues (2005) report that alcohol use causes low body perception.

In terms of licensed athletics, body perception scores of the participants become significantly different. The level of body perception of the students who are licensed athletes is higher than those who are not licensed athletes. Our research result in terms of sportive participation, shows that it arouses a positive mental emotion in individuals. In the literature, a wide array of works that supports our research results is observed. Neumark-Sztainer and his colleagues (2010) state that sportive participation causes an increase in the body satisfaction of the individual in their study. Again Loland 1998; Hausenblas and Fallon 2006; McFarlane \& Van Der Kolk 1996; Heather, Hausenblas and Downs, 2001; Featherstone 2010; Richman and Shaffer (2000), Aşçı and his colleagues (1993) point out the positive body image provided by sportive participation. Turner (1996) focused on healthy body image and regular exercise relationship. The author underlines the need for programmed sportive activities for a positive and healthy body image.

Negative, weak and significant correlations were detected according to the results of correlation analysis between body satisfaction levels and social appearance anxieties of our research group. This finding suggests that the hypothesis of the initial planning phase of the study is correct and stands as an expected result. Those whose body satisfaction were positive and high from the students who participated in the study reported low social appearance anxiety scores. These results are consistent with relevant studies (Martin, Rejeski, Leary, McAuley, \& Bane, 1997; Hart and his colleagues 1989; McAuley \& Burman, 1993; Kowalski his colleagues, 2001; Frederick \& Morrison).

The results of the study support the existing literature in the context of body perception and social appearance anxiety. In general, the literature on body perception and social appearance anxiety focuses on eating habits, substance use, healthy lifestyle habits, and sportive participation. Particularly, the positive contribution of sportive activities to physical perception after physical development is obvious. It is thought to be beneficial to use this effectively in the development of positive body perception and in reducing the social appearance anxiety.

\section{References}

Anbar, H. (2013) Analysis of the relationship of body perception variances with various variables in high school students and validity reliability study of body perception scale. Ankara University, Faculty of Language and History Geography, Department of Psychology, Undergraduate Thesis. Ankara.

Aşçı, F. H., Gökmen, H., Tiryaki, G., Aş̧̧ı, A., \& Zorba, E. (1993) The Impact of Sportive Participation on the Satisfaction Level of High-School Males from Their Body Parts, Sports and Performance Magazine, 4(3), 38-47.

Aslan, D. (2004) Nutrition Problems Caused by Body Perception Problems, 13(9), 326-329.

Clark, D. M., \& Wells, A. (1995). A cognitive model of social phobia. Social phobia: Diagnosis, assessment and treatment. Rumination And Negative Appraisal In Social Phobia. In, Heimberg RG, Liebowitz MR, Hope DA, Schneier FR (editors). New York: Guilford Press, 143-159.

Coopersmith, S. (1967). The antecedents of self-esteem. San Francisco: Freeman.

Crerand, C. E., Infield, A. L., \& Sarwer, D. (2007). Psychological Considerations in Cosmetic Breast Augmentation. Plastic Surgical Nursing, 27(3), 146-154. https://doi.org/10.1097/01.PSN.0000290284.49982.0c

Doğan, T. (2010). Turkish adaptation of the social anxiety scale: validity and reliability study. Hacettepe University Education Faculty Magazine, 39, 151-159.

Dökmen, Z. (1996). Psychometric Properties of the Turkish Form of Femininity and Masculine Scales of the Bem Gender Role Inventory. Kriz Magazine, 7(1), 27-39.

Dökmen, Z. Y. (2004). Social Gender, Sistem Publishing, 19, İstanbul.

Dolan, B., Birtchnell, S., \& Lacey, J. (1987). Body image distortion in non-eating disordered women and men. Journal of Psychosomatic Research, 31, 513-520. https://doi.org/10.1016/0022-3999(87)90009-2 
Ergür, E. (1996). The relationship between body-self perception and mental health in university students. Graduate Thesis, Ege University Institute of Social Sciences, İzmir.

Featherstone, M. (2010). Body, Image and Affectin Consumer Culture. Body \& Society, 16(1), 193-221. https://doi.org/10.1177/1357034X09354357

Franzoi, W., Kessenich, J., \& Sugrue, P. (1989). Gender differences in the experience of body awareness: An experiential sampling study. Sex Roles, 21, 499-515. https://doi.org/10.1007/BF00289100

Frederick, C. J., \& Morrison, C. S. (1996). Social physique anxiety: Personality constructs, motivations, exercise attitudes, and behaviors. Perceptual and Motor Skills, 82, 963-972. https://doi.org/10.2466/pms.1996.82.3.963

Göksan, B. (2007). Body image and body dysmorphic disorder in adolescents. Dissertation, Şişli Etfal Eğitim ve Araştırma Hastanesi, İstanbul.

Gümüş, E. A. (2000). The Relationship between Satisfaction Levels of Loneliness and Body Image with Social Anxiety Levels of the University Students. Journal of Faculty of Educational Sciences, Ankara University, 33, 99-108.

Harris, D. V. (1987). The Female Athlete. In J.R. May and M.J. Asken (Ed.). Sport Psychology: The Psychological Health of the Athlete. New York: PMA, 99-166.

Hart, E. A., Leary, M. R., \& Rejeski, W. J. (1989). The measurement of social physique anxiety. Journal of Sport \& Exercise Psychology, 11, 94-104. https://doi.org/10.1123/jsep.11.1.94

Hart, T. A., Flora, D. B., Palyo, S. A., Fresco, D. M., Holle, C., \& Heimberg, R. C. (2008). Development and Examination of the Social Appearance Anxiety Scale. Assessment, 15, 48-59. https://doi.org/10.1177/1073191107306673

Hausenblas, H. A., \& Fallon, E. A. (2006). Exercise and Body İmage: A Meta-Analysis. Psychology and Health, 21(1), 33-47. https://doi.org/10.1080/14768320500105270

Heather, A., Hausenblas, H., \& Downs, A. (2001). AssociationsBetween Body Satisfaction And Physical Activity İn Adolescents: Implications for Programs Aimed at Preventing A Broad Spectrum Of Weight-Related Disorders. Journal Of Applied Sport Psychology, 13, 323-339.

Herzog, D., Newman, K., Yeh, C., \& Warshaw, M. (1992). Body image satisfaction in homosexual and heterosexual women. International Journal of https://doi.org/10.1002/1098-108X(199205)11:4<391::AID-EAT2260110413>3.0.CO;2-F

Hovardaoğlu, S. (1993). Body perception scale. Psychiatry, Psychology, Psychopharmacology Journal, 1, 26.

Köse, E., Bayköse, N., Turan, E. B., \& Lapa, T. Y. (2016). The Role of Negative Evaluation Fear in Determining Body Perceptions in the Individuals that are Regularly Exercising. Mediterranean Journal of Humanities, VI(2), 351-360. https://doi.org/10.13114/MJH.2016.303

Kowalski, N. P., Crocker, P. R. E., \& Kowalski, K. C. (2001). Physical self and physical activity relationships in college women: Does social physique anxiety moderate effects? Research Quarterly for Exercise and Sport, 72, 55-62. https://doi.org/10.1080/02701367.2001.10608932

Kumcagiz, H. (2012). Pregnant women, body image and self-esteem according to the examination of some of the variables. Journal of Human Sciences, 9(2), 691-703.

Loland, N. W. (1998). Body Image and Physical Activity. A Survey Among Norwegian Men and Women. International Journal of Sport Psychology, 29(4), 339-365.

Martin, K. A., Rejeski, W. J., Leary, M. R., McAuley, E., \& Bane, S. (1997). Is the Social Physique Anxiety Scale really multidimensional? Conceptual and statistical arguments for a unidimensional model. Journal of Sport \& Exercise Psychology, 19, 359-367. https://doi.org/10.1123/jsep.19.4.359

McAuley, E., \& Burman, G. (1993). The Social Physique Anxiety Scale: Construct validity in adolescent females. Medicine \& Science in Sports \& Exercise, 25, 1049-1053. https://doi.org/10.1249/00005768-199309000-00013

Neumark-Sztainer, D. R., Friend, S. E., Flattum, C. F., Hannan, P. J., Story, M. T., Bauer, K. W., \& Petrich, C. A. (2010). New Moves - preventing weight-related problems in adolescent girls: A group-randomized study. American Journal of Preventive Medicine, 39, 421-432. https://doi.org/10.1016/j.amepre.2010.07.017

Nieri, T., Kulis, S., Keith, V. M., \& Hurdle, D. (2005). Body Image, Acculturation, and Substance Abuse Among Boys and Girls in the Southwest, The American Journal of Drug and Alcohol Abuse, 31(4), 617-639. https://doi.org/10.1081/ADA-200068418 
Öksüz, Y. (2012). The Relatıonshıp Between The Level Of Autonomous Behavior Of The Unıversity Students And Their Body Perceptıon. Gazi University Journal of Industrial Arts Education, 28, 69-77.

Öngören, B. (2015). Healthy Body Image from Sociological Point of View. Journal of Social and Humanities Researches, (34), 25-45.

Pınar, R. (2002). Depression, Self-Esteem and Body Image in Obese: A Comparative Study, C.Ü. Journal of Nursing School, 6, 30- 41.

Pulur, A., Üstün, E., \& Karabulut, E. O. (2014). The Effect of Smoking and Alcohol Use on the Perception Level of College High Level Folk Dance Sportsmen. Gazi University Journal of Gazi Educational Faculty, 29(3), 833-850.

Richman, E. L., \& Shaffer, D. R. (2000). If You Let Me Play Sport: How Might Female Sports Partcipation Influence the Self-Esteem of Adolescent Females, Psychology of female Quarterly, 24, 189-199.

Secord, P. F., \& Jourard, S. M. (1953). The appraisal of body cathexis: Body cathexis and the self. Journal of Consulting Psychology, 17, 343-347.

Stice, E., \& Shaw, H. E. (2002). Role of body dissatisfaction in the onset and maintenance of eating pathology A synthesis of research findings, Journal of Psychosomatic Research, 53, 985-993.

Sztainera, N., \& Storya, G. W. (2010). Comparison Of Body Image Between Athletes And Nonathletes: A Meta-Analytic Review, 125-137.

Tarhan, S. (1995). The impact of satisfaction level of high school students from their body images on self-esteem and academic achievement. Master Thesis, Hacettepe University Institute of Social Sciences, Ankara.

Tiegman, M. (2004). Body Image Across The Adult Life Span: Stability and Change. Body Image, 1(1), 29-41.

Traub, A., \& Orbach, J. (1964). Psychophysical studies o f body image: I. The adjustable body-distorting mirror. Archives of General Psychiatry, 11, 53-66. https://doi.org/10.1001/archpsyc.1964.01720250055007

Turner, S. W., McFarlane, A. C., \& Van Der Kolk, B. A. (1996). The Therapeutic Environment and New Explorations in the Treatment of Posttraumatic Stress Disorder. Ed. B. A. Van Der Kolk, A. C.

Uskun, E., \& Şabaplı, A. (2013). The Relationship Between Body Perception and Eating Attitudes of High School Students. TAF Preventive Medicine Bulletin, 12(5). https://doi.org/10.5455/pmb.1-1343135122

Walster, E., Aronson, V., Abrahams, D., \& Rottman, L. (1966). Importance of physical attractiveness in dating behavior. Journal of Personality and Social Psychology. 4, 508-516. https://doi.org/10.1037/h0021188

Wardle, J., \& Cooke, L. (2005). The impact of obesity on psychological well-being. Best Pract Res Clin Endocrinol Metab, 19(3), 421-440. https://doi.org/10.1016/j.beem.2005.04.006

Yentür, J. (2004). Comparison of Personality Structure with Perception Levels of Elite Female Sportsmen at National Team Level, Post-Graduate Thesis, Kırıkkale University, Institute of Health Sciences Department of Physical Education and Sport, Kırıkkale.

Yılmaz, I., \& Çelik, V. O. (2006). A Study on the Difference in the Perception of Body Image Between the Students in the Coaching Department and Sports Management Department, 9. International Sports Sciences Congress, 401, Muğla.

\section{Copyrights}

Copyright for this article is retained by the author(s), with first publication rights granted to the journal.

This is an open-access article distributed under the terms and conditions of the Creative Commons Attribution license which permits unrestricted use, distribution, and reproduction in any medium, provided the original work is properly cited. 